\title{
Modelling and optimization of sulfur addition during 70MnVS4 steelmaking: An industrial case study
}

\author{
Kovačič, M. ${ }^{\mathrm{a}, \mathrm{b}, \mathrm{c},{ }^{*},}$, Lešer, $\mathrm{B}^{\mathrm{a}},{ }^{\text {, Brezocnik, }} \mathbf{M}^{\mathrm{d}}{ }^{\mathrm{d}}$ \\ ǎtore Steel, d.o.o., Štore, Slovenia \\ ${ }^{\mathrm{b}}$ University of Ljubljana, Faculty of Mechanical Engineering, Ljubljana, Slovenia \\ ${ }^{c}$ College of Industrial Engineering Celje, Celje, Slovenia \\ ${ }^{d}$ University of Maribor, Faculty of Mechanical Engineering, Maribor, Slovenia
}

\begin{abstract}
A B S T R A C T
Štore Steel Ltd. is one of the major flat spring steel producers in Europe. Among several hundred steel grades, 70MnVS4 steel is also produced. In the paper optimization of steelmaking of 70MnVS4 steel is presented. 70MnVS4 is a high-strength microalloyed steel which is used for forging of connecting rods in the automotive industry. During 70MnVS4 ladle treatment, the sulfur addition in the melt should be conducted only once. For several reasons the sulfur is repeatedly added and therefore threatening clogging during continuous casting and as such influencing surface defects occurrence and steel cleanliness. Accordingly, the additional sulfur addition was predicted using linear regression and genetic programming. Following parameters were collected within the period from January 2018 to December 2018 (78 consequently cast batches): sulfur and carbon cored wire addition after chemical analysis after tapping, carbon, manganese and sulfur content after tapping, time between chemical analysis after tapping and starting of the casting, ferromanganese and ferrosilicon addition and additional sulfur cored wire addition. Based on modelling results it was found out that the ferromanganese is the most influential parameter. Accordingly, 12 consequently cast batches (from February 2019 to October 2019) were produced with as lower as possible addition of ferromanganese. The additional sulfur addition in all 12 cases was not needed. Also, the melt processing time, surface quality of rolled material and sulfur cored wire consumption did not change statistically significantly after reduction of ferromanganese addition. The steel cleanliness was statistically significantly better.
\end{abstract}

\section{ARTICLE INFO}

Keywords:

Metallurgy;

Steelmaking;

High-strength steel 70MnVS4;

Microalloyed steel;

Modelling;

Optimization;

Evolutionary algorithms;

Genetic programming;

Multiple linear regression

*Corresponding author: miha.kovacic@store-steel.si (Kovačič, M.)

Article history:

Received 3 April 2021

Revised 5 June 2021

Accepted 12 June 2021

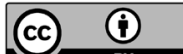

Content from this work may be used under the terms of the Creative Commons Attribution 4.0 International Licence (CC BY 4.0). Any further distribution of this work must maintain attribution to the author(s) and the title of
the work, journal citation and DOI.

\section{References}

[1] Szekely, J., Carlsson, G., Helle, L. (1989). Ladle metallurgy, Springer-Verlag, New York, USA, doi: 10.1007/978-14612-3538-5.

[2] Seetharaman, S. (2014). Treatise on process metallurgy, Volume 3: Industrial Processes, Elsevier, Oxford, United Kingdom, doi: 10.1016/C2010-0-67121-5.

[3] Holappa, L. (2014). Chapter 1.6 - Secondary steelmaking, In: Seetharaman, S. (ed.), Treatise on Process Metallurgy, Elsevier, Amsterdam, Netherlands, 301-345, doi: 10.1016/B978-0-08-096988-6.00012-2.

[4] Çamdali, Ü., Yetişken, Y., Ekmekçi, İ. (2012). Determination of the optimum cost function for an electric arc furnace and ladle furnace system by using energy balance, Energy Sources, Part B: Economics, Planning, and Policy, Vol. 7, No. 2, 200-212, doi: 10.1080/15567240903030521.

[5] Ekmekçi, I.., Yetisken, Y., Çamdali, Ü. (2007). Mass balance modeling for electric arc furnace and ladle furnace system in steelmaking facility in Turkey, Journal of Iron and Steel Research International, Vol. 14, No. 5, 1-6, doi: 10.1016/S1006-706X(07)60064-8.

[6] Singh, V., Reddy, K.V.K., Tripathy, S.K., Kumari, P., Dubey, A.K., Mohanty, R., Satpathy, R.R., Mukherjee, S. (2021). A 
sustainable reduction roasting technology to upgrade the ferruginous manganese ores, Journal of Cleaner Production, Vol. 284, Article No. 124784, doi: 10.1016/i.jclepro.2020.124784.

[7] Schade, J., Argyropoulos, S.A., McLean, A. (1990). Assimilation and recovery characteristics of innovative cored wire additions for stèelmaking, In: Bergman, R.A. (ed.), Proceedings of Metallurgical Society of Canadian Institute of Mining and Metallurgy, Ferrous and Non-Ferrous Alloy Processes, Pergamon Press, Ontario, Canada, 117-142, doi: 10.1016/B978-0-08-040411-0.50014-6.

[8] Savinov, R., Wang, Y., Shi, J. (2020). Microstructure and properties of $\mathrm{CeO}_{2}$-doped CoCrFeMnNi high entropy alloy fabricated by laser metal deposition, Journal of Manufacturing Processes, Vol. 56, Part B, 1245-1251, doi: 10.1016/i.jmapro.2020.04.018.

[9] Babu, S.S. (2022). Tools for alloy design, In: Caballero, F.G. (ed.), Encyclopedia of Materials: Metals and Alloys, Elsevier, Amsterdam, Netherlands, 245-262, doi: 10.1016/B978-0-12-819726-4.00142-3.

[10] Zhou, Y., Zhu, R., Wei, G. (2021). Application of submerged gas-powder injection technology to steelmaking and ladle refining processes, Powder Technology, Vol. 389, 21-31, doi: 10.1016/i.powtec.2021.05.003.

[11] Liu, Z., Zhang, L., Wang, M., Zhao, Z., Gao, L., Chu, M. (2021). New understanding on reduction mechanism and alloying process of rich manganese slag: Phase formation and morphological evolution, Powder Technology, Vol. 380, 229-245, doi: 10.1016/i.powtec.2020.11.071.

[12] Řeháčková, L., Novák, V., Váňová, P., Matýsek, D., Konečná, K., Smetana, B., Dobrovská, J. (2021). High temperature interaction of molten Fe-C-O-Cr alloys with corundum, Journal of Alloys and Compounds, Vol. 854, Article No. 157128, doi: 10.1016/i.jallcom.2020.157128.

[13] Chen, D., Lu, B., Chen, G., Yu, W. (2017). Influence of the production fluctuation on the process energy intensity in iron and steel industry, Advances in Production Engineering \& Management, Vol. 12, No. 1, 75-87, doi: 10.14743/apem2017.1.241.

[14] Natschläger, S., Stohl, K. (2007). Metallurgical simulation of the eaf-process, IFAC Proceedings Volumes, Vol. 40, No. 11, 207-211, doi: 10.3182/20070821-3-CA-2919.00030.

[15] Kovacic, M., Brezocnik, M. (2018). Reduction of surface defects and optimization of continuous casting of 70MnVS4 steel, International Journal of Simulation Modelling, Vol. 17, No. 4, 667-676, doi: 10.2507/IJSIMM17 (4) 457.

[16] Kovačič, M., Senčič, S. (2012). Modeling of pm10 emission with genetic programming, Materiali in tehnologije/Materials and technology, Vol. 46, No. 5, 453-457, from http://mit.imt.si/Revija/izvodi/mit125/kovacic.pdf, accessed April 13, 2021.

[17] Kovačič, M., Stopar, K., Vertnik, R., Šarler, B. (2019). Comprehensive electric arc furnace electric energy consumption modeling: A pilot study, Energies, Vol. 12, No. 11, Article No. 2142, doi: 10.3390/en12112142.

[18] Kovačič, M., Salihu, S., Gantar, G., Župerl, U. (2021). Modeling and optimization of steel machinability with genetic programming: Industrial study, Metals, Vol. 11, No. 3, Article No. 426, doi: 10.3390/met11030426.

[19] Brezocnik, M., Župerl, U. (2021). Optimization of the continuous casting process of hypoeutectoid steel grades using multiple linear regression and genetic programming - An industrial study, Metals, Vol. 11, No. 6, Article No. 972, doi: $10.3390 / \mathrm{m}$ et11060972.

[20] Montgomery, D.C., Runger, G.C. (2003). Applied statistics and probability for engineers, Third edition, John Wiley \& Sons, Hoboken, New Jersey, USA.

[21] Koza, J.R. (1992). Genetic programming: On the programming of computers by means of natural selection, MIT Press, Cambridge, USA.

[22] Gračnar, A., Kovačič, M., Brezocnik, M. (2020). Decreasing of guides changing with pass design optimization on continuous rolling mill using a genetic algorithm, Materials and Manufacturing Processes, Vol. 35, No. 6, 663-667, doi: 10.1080/10426914.2019.1645337.

[23] Amjad, M.K., Butt, S.I., Anjum, N., Chaudhry, I.A., Faping, Z., Khan, M. (2020). A layered genetic algorithm with iterative diversification for optimization of flexible job shop scheduling problems, Advances in Production Engineering \& Management, Vol. 15, No. 4, 377-389, doi: 10.14743/apem2020.4.372.

[24] Jurkovic, Z., Cukor, G., Brezocnik, M., Brajkovic, T. (2018). A comparison of machine learning methods for cutting parameters prediction in high speed turning process, Journal of Intelligent Manufacturing, Vol. 29, No. 8, 16831693, doi: $10.1007 / \mathrm{s} 10845-016-1206-1$.

[25] Kovačič, M., Župerl, U. (2020). Genetic programming in the steelmaking industry, Genetic Programming and Evolvable Machines, Vol. 21, 99-128, doi: 10.1007/s10710-020-09382-5.

[26] Stopar, K., Kovačič, M., Kitak, P., Pihler, J. (2017). Electric arc modeling of the EAF using differential evolution algorithm, Materials and Manufacturing Processes, Vol. 32, No. 10, 1189-1200, doi: 10.1080/10426914.2016. 1257859. 
APEM
Advances in Production Engineering \& Management
ISSN 1854-6250

Spletna stran: apem-journal.org Izvirni znanstveni članek

\title{
Modeliranje in optimizacija dodajanja žvepla med izdelavo jekla 70MnVS4: Študija industrijskega primera
}

\author{
Kovačič, M..$^{a, b, c, *}$, Lešer, B. ${ }^{a}$, Brezocnik, M. ${ }^{d}$ \\ aŠtore Steel, d.o.o., Štore, Slovenia \\ bUniversity of Ljubljana, Faculty of Mechanical Engineering, Ljubljana, Slovenia \\ cCollege of Industrial Engineering Celje, Celje, Slovenia \\ dUniversity of Maribor, Faculty of Mechanical Engineering, Maribor, Slovenia
}

\section{POVZETEK}

Štore Steel d.o.o. je eden večjih proizvajalcev ploščatih vzmetnih jekel v Evropi. Med več sto vrstami jekel se proizvaja tudi jeklo 70MnVS4. V prispevku je predstavljena optimizacija izdelave jekla 70MnVS4. 70MnVS4 je visoko trdno mikrolegirano jeklo, ki se uporablja za kovanje ojnic v avtomobilski industriji. Med pripravo 70MnVS4 v loncu je najbolj primerno žveplo $\mathrm{v}$ talino dodati samo enkrat. Iz različnih razlogov se žveplo doda večkrat, kar lahko povzroči zamašitev med neprekinjenim litjem in vpliva na pojav površinskih napak in na čistočo jekla. V skladu s tem je bil dodatni vnos žvepla predviden z uporabo linearne regresije in genetskega programiranja. V obdobju od januarja 2018 do decembra 2018 (78 zaporednih serij litja) so bili zbrani naslednji parametri: dodajanje žveplove in ogljikove žice po kemični analizi po izlivu, vsebnost ogljika, mangana in žvepla po izlivu, čas med kemično analizo po izlivu in začetkom litja, dodajanje feromangana in ferosilicija ter dodatno dodajanje žveplove žice. Na podlagi rezultatov modeliranja je bilo ugotovljeno, da je feromangan najvplivnejši parameter. Skladno s tem je bilo proizvedenih 12 zaporednih serij litja (od februarja 2019 do oktobra 2019) s čim manjšim dodatkom feromangana. Dodaten vnos žvepla v vseh 12 primerih ni bil potreben. Tudi čas obdelave taline, kakovost površine valjanega materiala in poraba žveplove žice se po zmanjšanju dodatka feromangana niso statistično značilno spremenili. Čistoča jekla je bila statistično značilno boljša.
\end{abstract}

\section{PODATKI O ČLANKU}

\section{Ključne besede:}

Metalurgija;

Proizvodnja jekla;

Jeklo visoke trdnosti 70MnVS4;

Mikrolegirano jeklo;

Modeliranje;

Optimizacija;

Evolucijski algoritmi;

Genetsko programiranje;

Večkratna linearna regresija

*Kontaktna oseba:

miha.kovacic@store-steel.si

(Kovačič, M.)

Zgodovina članka:

Prejet 3. aprila 2021

Popravljen 5. junija 2021

Sprejet 12. junija 2021

\section{(i)}

